\title{
STRATEGI KREATIF IKLAN LAYANAN MASYARAKAT (TINJAUAN PERANCANGAN ILM KARYA MAHASISWA DKV UDINUS)
}

\author{
Agus Setiawan \\ Program Studi Desain Komunikasi Visual \\ Fakultas IImu Komputer, Universitas Dian Nuswantoro \\ wawansetiawan18@yahoo.co.id
}

\begin{abstract}
Abstrak
Keberadaan Iklan Layanan Masyarakat sendiri selalu berkembang mengikuti peradaban masyarakat, teknologi dan sosial di masyarakat. Komunikasi visual sebagai kekuataan dalam strategi penyampai pesan iklan dipandang sebagai bahasa, maka visualisasi iklan mencakup struktur tanda yang memiliki makna. Pemilihan iklan layanan masyarakat sebagai pijakan kreatif karena dalam perancangan melibatkan konsep-konsep dan strategi kreatif sehingga mampu mewujudkan karya yang memberl pesan kuat. Tujuannya strategi komunikasi visual adalah agar pesan yang disampaikan melalui beberapa media dapat menarik beberapa khalayak. Strategi kreatif dalam rancangan ini mencakup beberapa pendekatan di antaranya: pendekatan isi pesan, what to say, dan how to say. Media ditentukan berdasarkan pertimbangan media habit, efektivitas media, dan biaya relatif (efisiensi biaya). Visualisasi iklan diwujudkan dengan mengembangkan ilustrasi dan menggabungkan gambar, headline, logo, dan tagline disertai dengan layout. Media yang digunakan adalah poster, billboard, banner, kaos, iklan surat kabar, leaflet, sticker, topi, pin, tote bag dan gantungan kunci. Teknik fotografi digunakan untuk memperkuat gambar.
\end{abstract}

Kata kunci: strategi, kreatif, iklan

\section{PENDAHULUAN}

Menurut Kamus Besar Bahasa Indonesia (KBBI), iklan mempunyai dua arti yaitu: 1) Berita pesanan (untuk mendorong, membujuk) kepada khalayak ramai tentang benda dan jasa yang ditawarkan; 2) Pemberitahuan kepada khalayak ramai mengenai barang atau jasa yang dijual, dipasang dalam media massa seperti surat kabar dan majalah. Sedangkan, menurut Durianto (2003:10) pengertian iklan merupakan suatu proses komunikasi yang bertujuan untuk membujuk dan menggiring orang untuk mengambil tindakan yang menguntungkan bagi pihak pembuat iklan. Adapun, Kriyantono (2008:15) menambahkan, bahwa iklan didefinisikan sebagai bentuk komunikasi nonpersonal yang menjual pesan-pesan persuasive dari sponsor yang jelas, untuk mempengaruhi orang membeli produk atau jasa, dengan membayar sejumlah uang sebagai media pemasangan iklan. Bentuk komunikasi yang mewujud dalam iklan membutuhkan konsep dan strategi, supaya berita, proses, dan pesan yang ada dalam iklan dapat di pahami masyarakat.

Istilah Iklan layanan Masyarakat menurut Pujiyanto (2014:12) diartikan iklan yang digunakan untuk menyampaikan informasi, mengajak atau mendidik khalayak dimana tujuan akhir bukan untuk mendapatkan keuntungan ekonomi, melainkan keuntungan sosial. Memahami informasi untuk keuntungan sosial adalah pengetahuan, kesadaran 
sikap dan perubahan perilaku masyarakat. Di sisi lain, iklan juga untuk mendapatkan citra yang baik di mata masyarakat. Iklan Layanan Masyarakt muncul didasari oleh kondisi lingkungan dan perilaku yang berdampak pada permasalahan sosial.

Keberadaan Iklan Layanan Masyarakat sendiri selalu berkembang mengikuti peradaban masyarakat, teknologi dan sosial di masyarakat. Iklan Layanan Masyarakat memiliki peran penting bagi berbagai kegiatan non-bisnis, karena dipandang dapat menggerakkan solidaritas masyarakat pada masalah-masalah social. Komunikasi visual sebagai strategi penyampai pesan iklan dipandang sebagai bahasa, maka visualisasi iklan mencakup struktur tanda yang memiliki makna. Melalui bahasa visual lebih memiliki kesempatan dalam memahami konsentrasi target sasaran (Yayan Suherlan, 2010:236). Berkenaan dengan Iklan Layanan Masyarakat yang sudah dipaparkan di atas, maka penulis meninjau dari perancangan Iklan Layanan Masyarakat karya mahasiswa Desain Komunikasi Visual. Adapun pijakan pemikiran berkaitan dengan strategi kreatif dalam iklan layanan masyarakat adalah Perancangan Iklan Layanan Masyarakat Sebagai Kampanye Penggunaan Bbm Non Subsidi karya Mashur dan Perancangan Iklan Layanan Masyarakat Tentang Pentingnya Penanaman Mangrove Di Kelurahan Tugurejo Semarang Guna Pencegahan Abrasi Karya Reza Yuliyanto Tri Wibowo. Penulisan difokuskan pada aspek strategi kreatif yang mencakup komunikasi visual.

Pada dasarnya periklanan mempunyai fungsi utama yaitu sebagai upaya pemasaran dan komunikasi. Kegiatan pemasaran meliputi strategi pemasaran, yaitu logika pemasaran yang diterapkan oleh unit bisnis guna mencapai tujuan pemasaran (Kotler, 1991: 416), sedangkan kegiatan komunikasi adalah perwujudan interaksi perorangan dengan menerapkan tanda-tanda yang tegas. Adapun, kata komunikasi berasal dari bahasa Latin communis yang artinya sama, dan communico, communicatio, atau communicare yang berarti 'membuat sama'. Pengertian komunikasi sendiri menurut Laswell (2011: 8) adalah proses yang menggambarkan siapa mengatakan dengan cara apa, kepada siapa dengan efek apa. Kemudian, Theodorson dan Thedorson menjelaskan bahwa, komunikasi adalah penyebaran informasi, ide-ide sebagai sikap atau emosi dari seseorang kepada orang lain terutama melalui simbol-simbol. Pengertian ini pun di perkuat dengan adanya penjelasan dari William Albig bahwa komunikasi adalah proses sosial, dalam arti pelemparan pesan / lambang, yang mana mau tidak mau akan menumbuhkan pengaruh pada semua proses dan berakibat pada bentuk perilaku manusia dan adat kebiasaan. Berdasarkan pemahaman komunikasi di atas, maka komunikasi merupakan perwujudan interaksi yang tercipta melalui visual, tanda, media, dan budaya. Aspek komunikasi visual menjadi bagian dari strategi kreatif iklan dan berada pada wilayah desain komunikasi visual.

Desain Komunikasi Visual bisa dikatakan adalah seni menyampaikan pesan (arts of commmunication) dengan menggunakan bahasa rupa (visual language) yang disampaikan melalui media berupa desain. Dengan tujuan menginformasikan, mempengaruhi hingga merubah perilaku target audience sesuai dengan tujuan yang diinginkan. Bahasa rupa yang dipakai berbentuk grafis, tanda, simbol, ilustrasi 
gambar/foto, tipografi/huruf dan sebagainya yang disusun berdasarkan khaidah bahasa visual yang khas. Tinarbuko (1998:66) menjelaskan, bahwa desain komunikasi visual dapat dipahami sebagai bentuk upaya pemecahan masalah untuk menghasilkan suatu desain yang inovasi diantara desain yang baru. Dalam proses kreatif, pada dasarnya rancangan desain komunikasi visual bekerja atas dasar beberapa pertimbangan pasar yang meliputi segmentasi, targeting, dan positioning.

\section{PEMBAHASAN}

\subsection{Strategi Kreatif Iklan}

Strategi komunikasi visual yang diwujudkan guna menghasilkan karakteristik pesan yang kuat. Adapun tujuannya adalah agar pesan yang disampaikan melalui beberapa media dapat menarik beberapa khalayak. Strategi kreatif dalam rancangan ini mencakup beberapa pendekatan di antaranya: pendekatan isi pesan, what to say, dan how to say. Sehingga Iklan yang disampaikan kepada masyarakat dapat dipahami, menarik, dan menumbuhkan efek yang kuat. Adapun kajian dan pendekatan yang dilakukan dalam rancangan Iklan layanan masyarakat sebagai berikut:

a) Pendekatan Isi Pesan

Pendekatan penyampaian pesan pada iklan layanan masyarakat ini adalah dengan menyajikan daya tarik rasional, yaitu pesan yang berisi tentang realitas yang nantinya dapat diterima dengan mudah oleh audience. Dengan pendekatan ini diupayakan membangkitkan kesadaran audience untuk melakukan sesuatu yang dianggap benar.

b) What To Say

Pesan yang ingin disampaikan pada iklan layanan masyarakat ini adalah agar audience dapat mengetahui dan lebih tanggap terhadap keadaan di lingkungan sekitar. Proses adaptasi dari realitas ke dalam visualisasi iklan.

c) How To Say

Cara yang dipakai untuk menyampaikan pesan pada iklan layanan masyarakat ini yaitu dengan mewujudkan simbol-simbol. Melalui tanda-tanda sebagai komunikasi visual dapat memudahkan audience melihat kejadian nyata yang terjadi, sehingga dapat melakukan tindakan lebih lanjut.

Strategi kreatif yang diterapkan menggunakan perpaduan media. Apabila tujuan media berdasarkan pada reach, frequency, dan continuity, maka paduan media yang ditentukan juga berdasarkan reach, frequency, dan continuity. Tujuan diadakannya pemilihan media adalah untuk efektivitas komunikasi dan efisiensi biaya, untuk mencapai tujuan media yang sudah ditentukan, maka paduan media ditentukan berdasarkan pertimbangan berikut:

1) Media Habit yaitu media yang menjadi kebiasaan target audiens dalam, membaca, melihat, dan mendengar.

2) Efektivitas media yaitu media yang tepat dalam mengkomunikasikan isi/pesan yang ingin disampaikan, dilihat dari karakteristik medianya.

3) Biaya relatif (efisiensi biaya) yaitu biaya yang bisa dicapai berdasarkan kemampuan yang ada dan pertimbangan dampak yang diperoleh. 


\subsection{Strategi Kreatif ILM tentang Penggunaan Bbm Non Subsidi}

Iklan layanan masyarakat tentang penggunaan Bbm Non Subsidi adalah untuk menyadarkan dan mendorong masyarakat terutama yang mampu untuk beralih menggunakan BBM non subsidi. Sehingga subsidi BBM dari pemerintah bisa tepat sasaran, dan dana pada subsidi bisa dialokasikan pada perbaikan jalan, pembangunan, kesehatan, pendidikan, dan yang lain yang lebih bermanfaat.

Adapun konsep yang diusung adalah menceritakan kendaraan yang selalu ada ketika dibutuhkan, disegala cuaca, selalu berusaha memberikan yang terbaik. Tetapi sudahkah kita membalasnya dengan memberikan yang terbaik untuknya. Dengan konsep tersebut maka, Headline yang digunakan untuk mendukung pesan yang ingin disampaikan adalah "PERTAMAX ISTIMEWA". Dimana dalam pengaplikasian pada media nanti akan ditunjang dengan tambahan kata-kata yang menyesuaikan dengan konsep image agar lebih mengarah sesuai dengan tujuan yang ingin dicapai. Strategi visual iklan layanan masyarakat ini menerapkan gambar mobil atau ikon yang dapat mewakili mobil sebagai elemen untuk menarik perhatian (eye-catcher) yang didukung dengan headline yang tepat untuk menyampaikan pesan terhadap audience.

\subsubsection{Iklan Layanan Masyarakat dengan media Billboard}

Strategi kreatif iklan layanan masyarakat ini pada dasarnya diawali dengan ilustrasi. Rancangan ilustrasi ini menggambarkan sebuah mobil tampak samping yang mengambil bagian belakang dengan tempat bahan bakar dibiarkan terbuka. Visualisasi tempat bahan bakar yang terbuka sebagai fokus tempat pengisisan bahan bakar. Dengan pesan yang ingin disampaikan adalah berikan yang terbaik untuk kendaraan anda. Iklan layanan masyarakat ini divisualisasikan menggunakan mobil jenis sedan sebagai perwakilan kendaraan roda empat kelas menengah atas. Posisi pengambilan foto dari samping dengan pengambilan gambar setengah bagian belakang untuk fokus pada tempat pengisian bahan bakar.
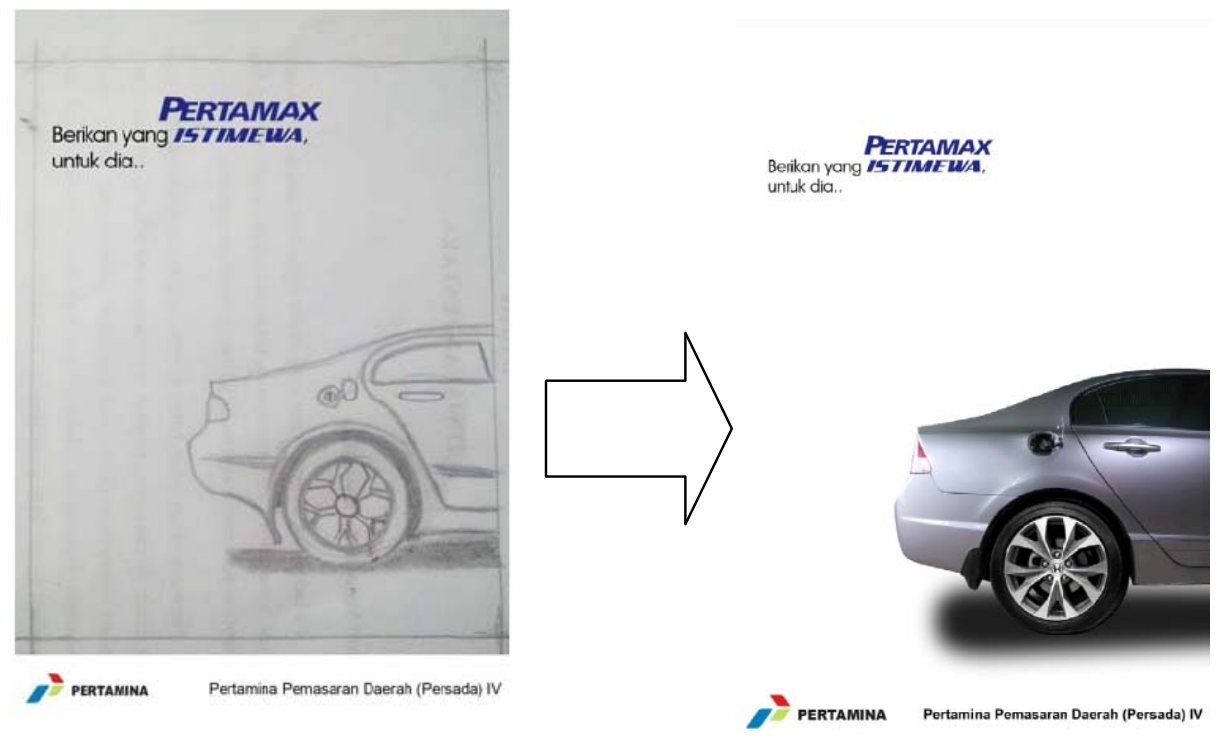

Gambar 1. Desain dan ilustrasi yang dirancang pada media Billboard

(Mashur,2015) 
Adapun rancangan layout memanfaatkan white space dengan menempatkan posisi mobil di sudut kanan bawah sebagai point of interest. Mobil tersebut juga berfungsi sebagai ruang positif dan sebagai elemen utama untuk menjadi subjek dalam menyampaikan pesan. Arah kanan pada mobil menunjukan hal positif yang ingin disampaikan dan yang ingin dicapai. Penempatan headline berada di sudut kanan atas terkesan dinamis dan balance. Headline : Berikan yang istimewa untuk dia mengandung makna bahwa masyarakat mampu yang menggunakan mobil pribadi untuk beralih menggunakan BBM non subsidi atau pertamax.

\subsubsection{Iklan Layanan Masyarakat dengan media online}

Strategi kreatif iklan layanan masyarakat ini secara ilustrasi menggambarkan seorang pengemudi mobil sedang berbicara kepada orang yang duduk di belakang. Orang yang duduk dibelakang tersebut maksutnya adalah masyarakat yang menjadi target audience. Visualisasi iklan menggunakan media kaca spion depan yang mengilustrasikan seolah-olah pengemudi mengajak bicara orang yang duduk di bagian belakang, dimana orang yang dimaksut adalah masyarakat luas (target audience). Kaca spion depan juga menyimbolkan kendaraan beroda 4, karena target yang dituju adalah pengguna mobil pribadi. Penerapan figur seorang laki-laki berkacamata sebagai penyampai pesan, karena pengguna kendaraan bermotor dijalanan lebih banyak lakilaki yang mengemudikan, meskipun tidak menutup kemungkinan pesan ditujukan juga untuk kaum hawa. Karakter laki-laki tersebut dibuat lebih tegas, berwibawa, dan mengintimidasi untuk membantu tercapainya pesan kepada audience.

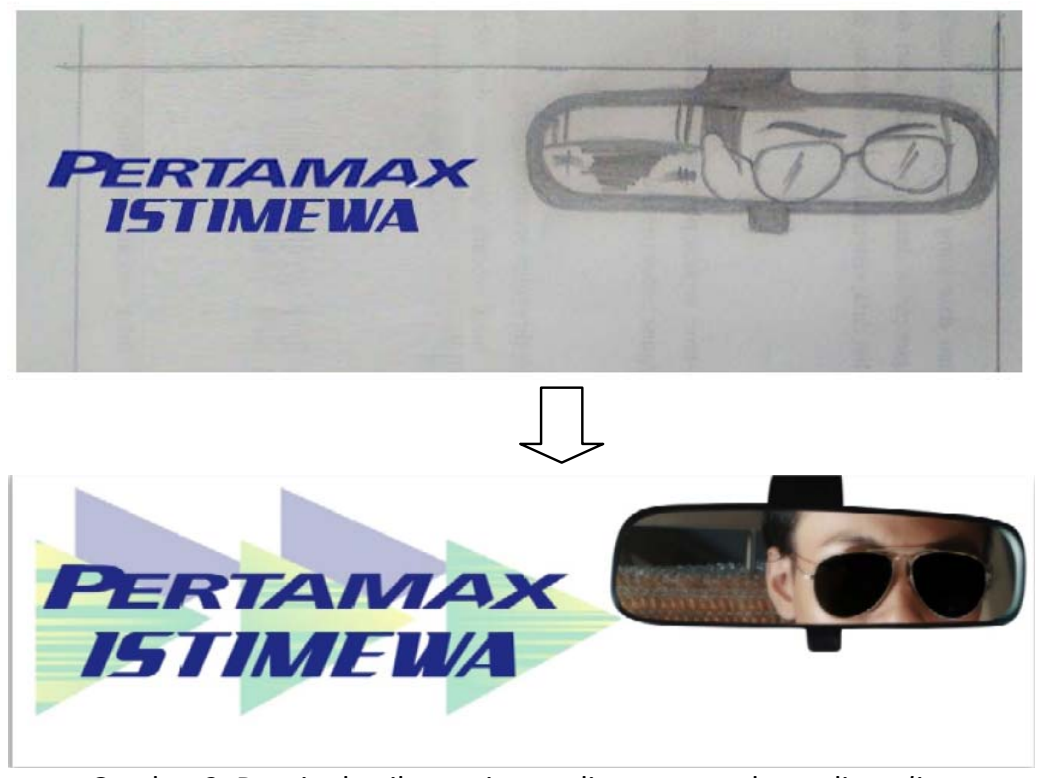

Gambar 2. Desain dan ilustrasi yang dirancang pada media online

(Mashur, 2015)

Secara Layout : Penempatkan posisi kaca spion depan di sudut kanan atas sebagai point of interest yang menjadi subjek dalam menyampaikan pesan. Font diletakan di sebalah kiri dengan ukuran huruf yang besar sebagai penegasan akan pesan yang ingin disampaikan. Adapun, Headline : Pertamax Istimewa mengandung makna bahwa bahan bakar pertamax bukan bahan bakar biasa, pertamax memiliki banyak 
keunggulan dan merupakan produk andalan pertmaina yang direkomendasikan untuk kendaran yang diproduksi di atas tahun 1990 terutama yang menggunakan mesin injeksi.

\subsubsection{Iklan Layanan Masyarakat dengan media surat kabar/Koran}

Ilustrasi ini menggambarkan pemandangan lautan saat matahari terbenam yang air lautnya sedang surut sehingga pemandangannya tidak terlalu indah, namun di tengahtengah ada lubang berbentuk 1/4 lingkaran yang dihasilkan dari pembersih kaca pada mobil dan di tengah lubang tersebut tampak pemandangan indah. Dengan pesan yang ingin disampaikan adalah berikan yang terbaik untuk dia. Strategi visual menerapkan lanscape pemandangan alam yang enak untuk dilihat, konsep tersebut digunakan untuk menyampaikan pesan dalam ILM ini, dengan menampilkan 2 pemandangan sunset yang berbeda, yaitu pemandangan sunset saat air laut surut dan sunset yang indah dengan siluet perahu. Sunset saat air laut surut mewakili BBM subsidi yang tidak tepat sasaran, sedangkan sunset dengan siluet perahu yang indah mewakili BBM subsidi yang tepat sasaran. Penggunaan pemandangan alam karena pertamax merupakan bahan bakar yang ramah lingkungan. Oleh karena itu harus menghemat energi untuk keberlangsungan anak cucu kita nanti. windscreen wiper (alat pemberesih kaca pada mobil) Menyimbolkan kendaraan roda 4/mobil pribadi yang menjadi target dalam ILM ini.

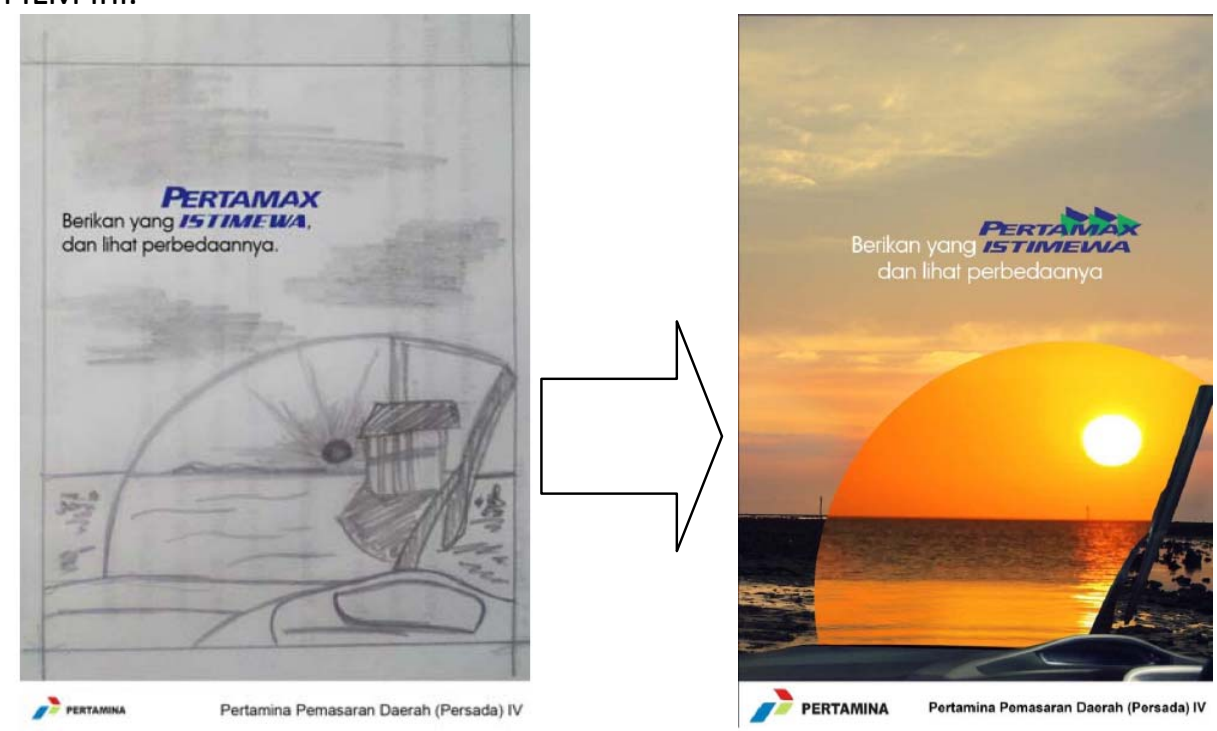

Gambar 3. Desain dan ilustrasi yang dirancang pada media surat kabar

(Mashur,2015)

Adapun, Layout: Penempatkan posisi windscreen wiper berada di tengah bawah sebagai point of interest, untuk menyampaikan pesan. Dan bagian atas dibiarkan kosong untuk memberi ruang istirahat bagi orang yang melihat biar tidak jenuh. Headline: Berikan yang istimewa dan lihat perbedaanya mengandung makna bahwa masyarakat mampu yang menggunakan mobil pribadi untuk beralih menggunakan BBM non subsidi atau pertamax, karena membuat mesin lebih responsif dan membuat umur mesin makin awet karena pertamax tidak mengandung timbal. 


\subsubsection{Iklan Layanan Masyarakat dengan media Tabloid}

Ilustrasi ini menggambarkan sebuah mobil yang di ajak jalan-jalan di luar kebiasaannya. Yang biasanya di jalannan beraspal di perkotaan, tetapi ini di jalanan tanah di perbukitan. Namun tidak menjadi masalah karena mobil tersebut menggunakan BBM non subsidi. Dengan pesan yang ingin disampaikan adalah berikan yang terbaik untuk dia. Objek iklan menggunakan mobil jenis sedan untuk mewakili kendaraan roda 4 kelas menengah atas. Dalam desain tersebut menggunakan mobil tunggal sebagai simbol atau perwakilan terhadap masyarakat yang mampu yang seharusnya menggunakan BBM non subsidi. Dalam ilustrasi tersebut menggambarkan sebuah mobil yang di ajak jalan-jalan di luar kebiasaannya. Yang biasanya di jalannan beraspal di perkotaan, tetapi ini di jalanan tanah di perbukitan.
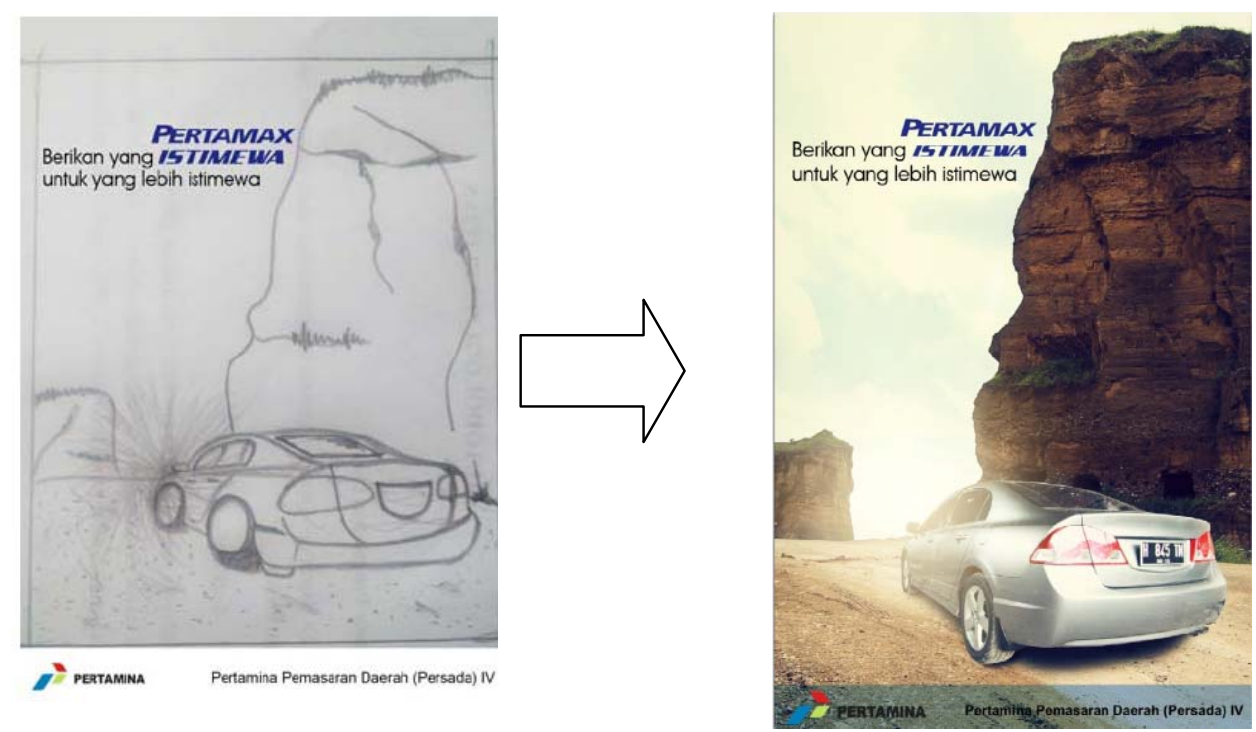

Gambar 4. Desain dan ilustrasi yang dirancang pada media surat kabar

(Mashur,2015)

Layout: Penempatan mobil di depan sebagai foreground dan penarik perhatian, karena mobil tersebut merupakan subjek utama dalam penyampaian pesan. Headline : Berikan yang istimewa untuk dia yang beda mengandung makna bahwa menggunakan pertamax akan membuat kendaraan anda berbeda. Mesin akan lebih responsif.

\subsection{Strategi Kreatif ILM tentang Pentingnya Penanaman Mangrove Di Kelurahan Tugurejo Semarang Guna Pencegahan Abrasi}

Rancangan kreatif iklan layanan masyarakat tentang pentingnya penanaman mangrove guna mengurangi abrasi di kelurahan tugurejo didapatkan perpaduan media antara lain: Media Poster, Billboard, Banner, Kaos, Surat Kabar "Suara Merdeka", Leaflet, Stiker, Topi, Pin, Tote bag, Gantungan Kunci.

\subsubsection{Iklan Layanan Masyarakat dengan media poster}

Media poster digunakan sebagai penarik perhatian untuk menggugah target audience agar tertarik melakukan pesan-pesan yang disampaikan dalam poster tersebut. Pemasangan poster berada di tempat informasi yang telah disediakan seperti mading 
umum, mading kampus, sekolahan, perkantoran. Pemilihan poster sebagai media primer, karena lebih efektif, mudah dijangkau kesemua daerah yang akan di pasang poster dan biaya yang murah untuk cetak massal. Dalam hal ini, poster di yang di tempelkan akan berbeda tema, tapi dengan maksud yang sama, tema yang berbeda dikarenakan oleh lokasi yang berbeda dan jangkauan yang berbeda.
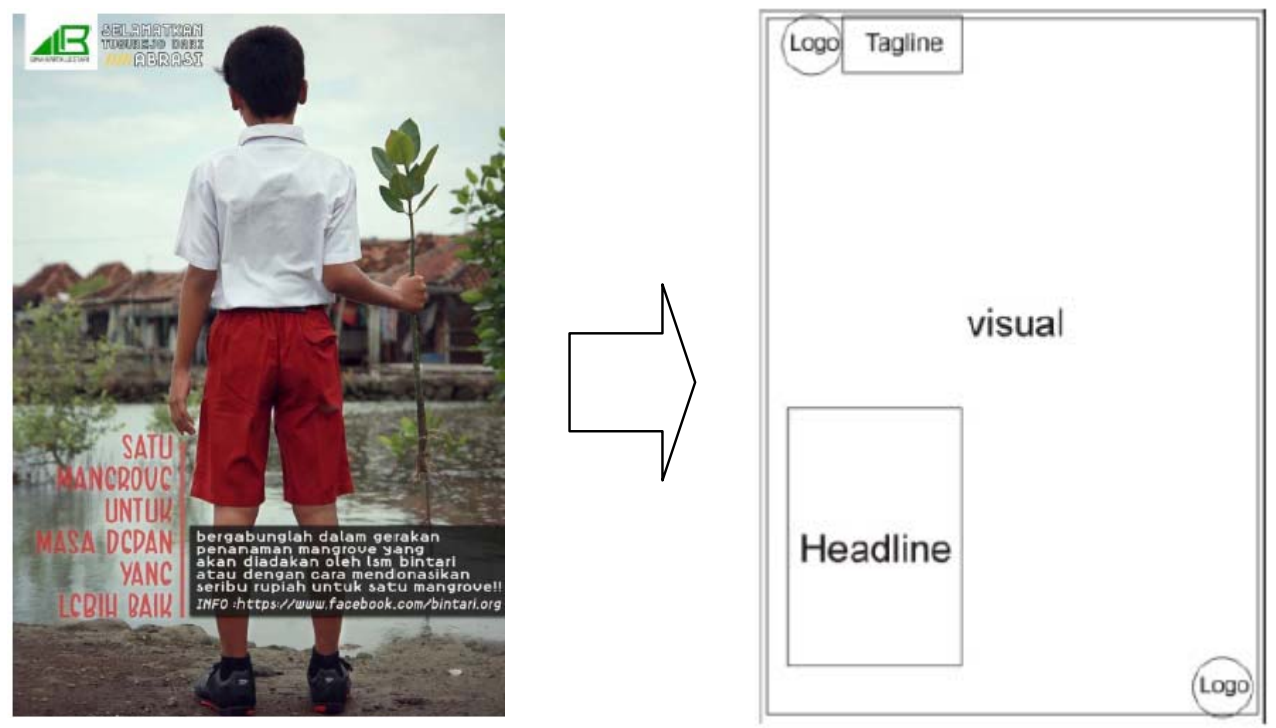

Gambar 5. Rancangan Poster tentang penanaman mangrove

(Reza, 2015)

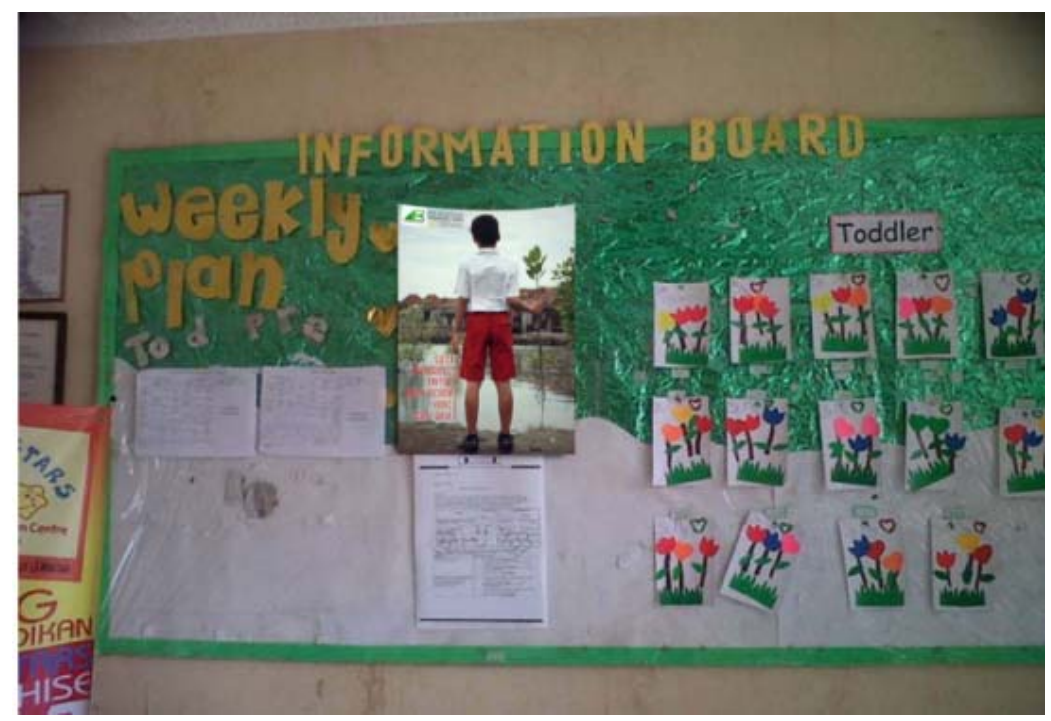

Gambar 6. Penerapan pada madding sekolah

(Reza, 2015)

Karya di atas divisualisasikan dengan ukuran A3 $(297 \times 420 \mathrm{~mm})$ dengan bahan Ivory. Headline : "Satu mangrove untuk masa depan yang lebih baik" dan Tagline : "Selamatkan Tugurejo dari abrasi" berwarna merah. poster ini ditempatkan di madding 
sekolah, perkantoran dan kampus. Secara kreatif layout poster: headline di tempakkan di sebelah kiri bawah, logo ditempatkan di sebelah kiri atas. Sedangkan tagline ditempatkan berada disebelah kalan logo. Adapaun secara keseluruhan dipenuhi dengan gambar anak dan perumahan sebagai bacground. Gambar anak berpakaian seragam merah putih menghadap kearah perkampungan. Gambar anak divisualisasikan tampak belakang sambil memegang tanaman mangrove dengan tangan kanannya. Berdasarkan visual secara keseluruhan dapat di interpretasikan bahwa pentingnya penanaman mangrove sejak dini untuk menyelamatkan sebuah perkampungan yang berada di tepi laut. Ancaman abrasi menjadi factor penting dalam kelestarian lingkungan. Iklan layanan masyarakat ini di terapkan pada madding sekolah.

\subsubsection{Iklan Layanan Masyarakat dengan media Billboard}

Media ini memiliki tingkat frekuensi yang cukup tinggi dimana aktivitas dan rutinitas kehidupan masyarakat kota Semarang yang cukup tinggi. Media ini akan dipasang di titik strategis seperti diarea jembatan pandanaran sebagai media pengingat.
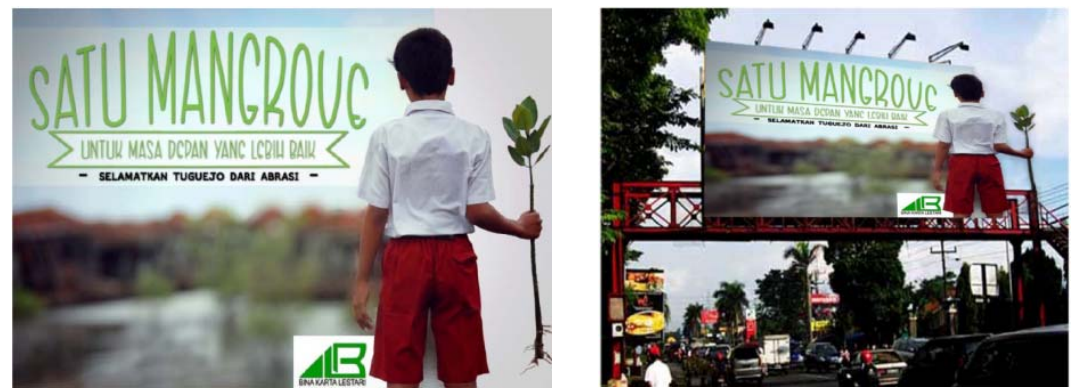

Gambar 7. Rancangan dan Penerapan ILM tentang mangrove di media billboard

(Reza, 2015)

Rancangan iklan layanan masyarakat dengan media billboard divisualisasikan dengan ukuran 4,5 x 3 m dengan bahan MMT. Headline: "Satu mangrove untuk masa depan yang lebih baik" dan Tagline : "Selamatkan Tugurejo dari abrasi" berwarna merah. Biilboard ini ditempatkan dijembatan pandanaran. Secara kreatif layout billboard: headline di tempakkan di bagian atas dengan proposi $50 \%$ dari ukuran billboard. logo ditempatkan di sebelah kiri gambar anak. Sedangkan tagline ditempatkan berada dibawah Headline. Adapaun secara keseluruhan dipenuhi dengan gambar anak dan perumahan sebagai background yang diwujudkan secara kabur. Gambar anak berpakaian seragam merah putih menghadap kearah alam. Gambar anak divisualisasikan tampak belakang sambil memegang tanaman mangrove dengan tangan kanannya. Berdasarkan visual secara keseluruhan dapat di interpretasikan bahwa pentingnya penanaman mangrove sejak dini untuk menyelamatkan sebuah perkampungan yang berada di tepi laut. Ancaman abrasi menjadi factor penting dalam kelestarian lingkungan. 


\subsubsection{Iklan Layanan Masyarakat dengan media banner}

Media iklan berupa MMT membentang yang biasanya dipasang di pinggir jalan. Di tempatkan di Tempat iklan resmi seperti dekat lampu merah. Kelebihan: audiens dapat mengatur tempo dalam membaca pesan, sifatnya tercetak dan pesannya bersifat permanen, media ini dapat tahan lama dan dapat dilihat dari jarak jauh. ekurangan: Diperlukan kemampuan membaca dan atensi yang tinggi, membutuhkan proses penyusunan dan penyebaran yang kompleks dan membutuhkan waktu yang relatif lama.

Rancangan iklan layanan masyarakat dengan media banner di visualisasikan dengan ukuran 4,5 x 3 m dengan bahan MMT. Headline : "Satu mangrove untuk masa depan yang lebih baik" dan Tagline: "Selamatkan Tugurejo dari abrasi" berwarna merah. Biilboard ini ditempatkan dijembatan pandanaran. Secara kreatif layout banner: headline di tempakkan di sebelah kiri bawah, logo ditempatkan di sebelah kiri atas. Sedangkan tagline ditempatkan berada disebelah kalan logo. Adapaun secara keseluruhan dipenuhi dengan gambar anak dan perumahan sebagai bacground. Gambar anak berpakaian seragam merah putih menghadap kearah perkampungan. Gambar anak divisualisasikan tampak belakang sambil memegang tanaman mangrove dengan tangan kanannya. Adapun banner yang disebelah kanan diwujudkan dengan gambar rumah yang sudah terkena abrasi. Namun, dengan kesadaran masyarakat sudah menunjukkan peran masyarakat dengan menanam mangrove. Berdasarkan visual secara keseluruhan dapat di interpretasikan bahwa pentingnya penanaman mangrove sejak dini untuk menyelamatkan sebuah perkampungan yang berada di tepi laut juga kepedulian terhadap lingkungan. Mengingat ancaman abrasi menjadi faktor penting dalam kelestarian lingkungan.
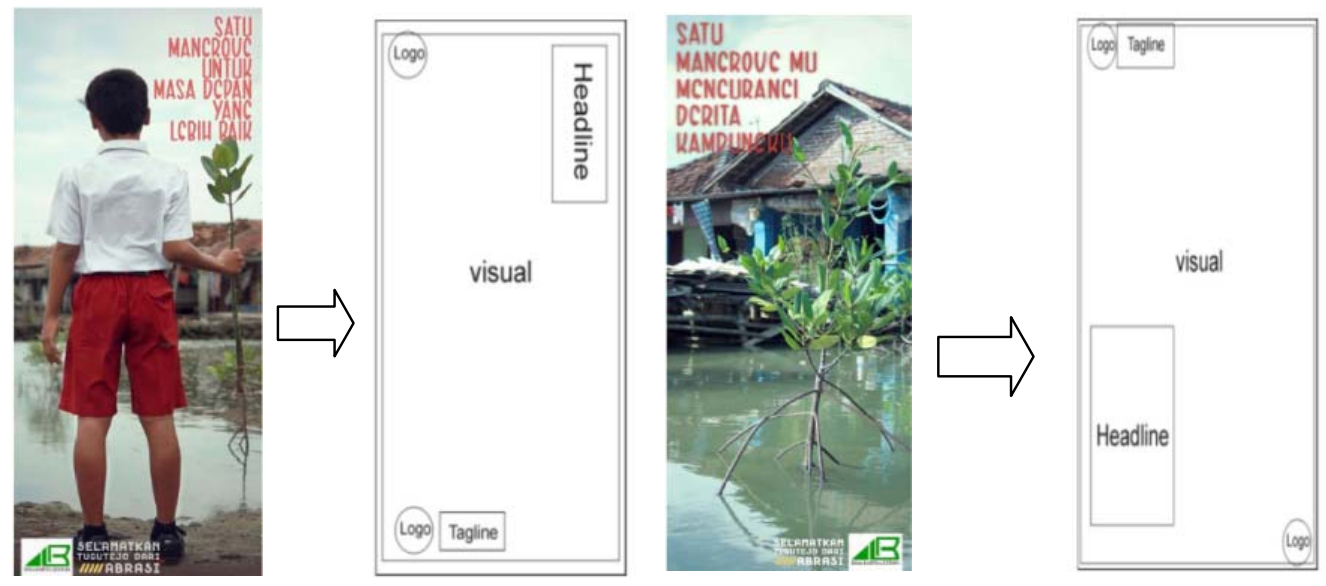

Gambar 8. Rancangan ILM dengan media banner

(Reza, 2015) 


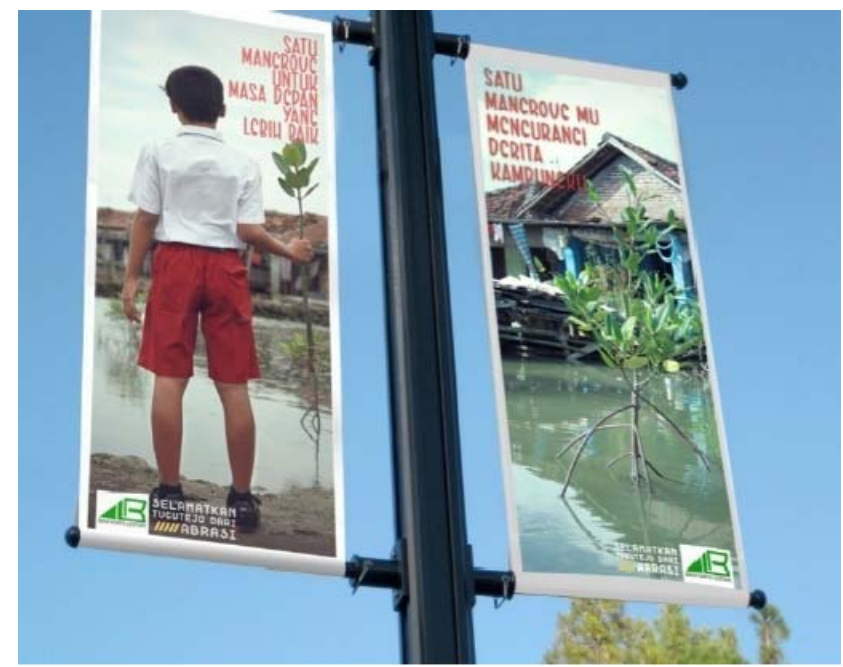

Gambar 9. Penerapan ILM dengan media banner

(Reza, 2015)

\subsubsection{Iklan Layanan Masyarakat dengan media kaos}

Media kaos ini dirancang karena merupakan media pendukung yang memiliki pengaruh yang besar terhadap keberhasilan sosialisasi ini. Kaos merupakan media yang dapat dipakai sebagai pendukung sosialisasi sehingga pesan yang terdapat pada kaos dapat terbaca dan terlihat oleh masyarakat dimana pemakai kaos berada sebagai penyampai pesan.Kaos ini nantinya dibagikan kepada peserta penanaman mangrove. Kelebihan : Media promosi yang berjalan dan berdaya guna. Kekurangan : Tidak dipakai secara terus menerus dalam kehidupan sehari-hari.

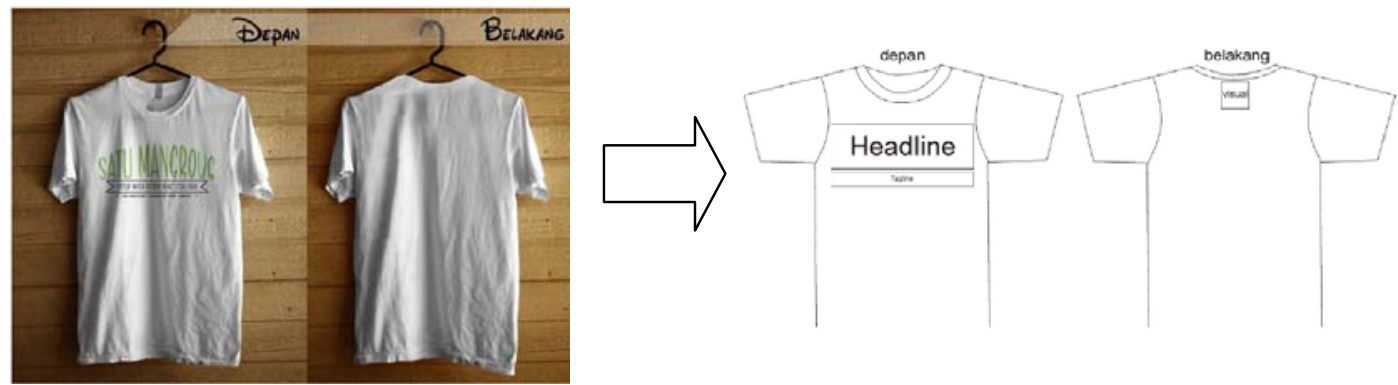

Gambar 10. Rancangan desain ILM pada media kaos

(Reza, 2015)

\subsubsection{Iklan Layanan Masyarakat dengan media surat kabar}

Media surat kabar adalah jenis iklan yang tercetak pada surat kabar dan mengharuskan komisi pada biro iklan/surat kabar tersebut. Kelebihan: Merupakan media promosi yang dapat menampilkan produk dengan menarik, dapat menjangkau khalayak audiens secara selektif, memberikan cakupan lengkap dan tidak dibatasi pada kelompok demografi dan sosial ekonomi (hampir setiap orang membaca surat kabar/koran). Karena sifatnya tercetak, pesan-pesannya bersifat permananen dan kekuatan utamanya adalah dapat dijadikan bukti. Kekurangan: Biaya mahal, pesan dan informasi 
terbatas pada konsumen yang membeli surat kabar tersebut, tidak memiliki usia baca sepanjang majalah.

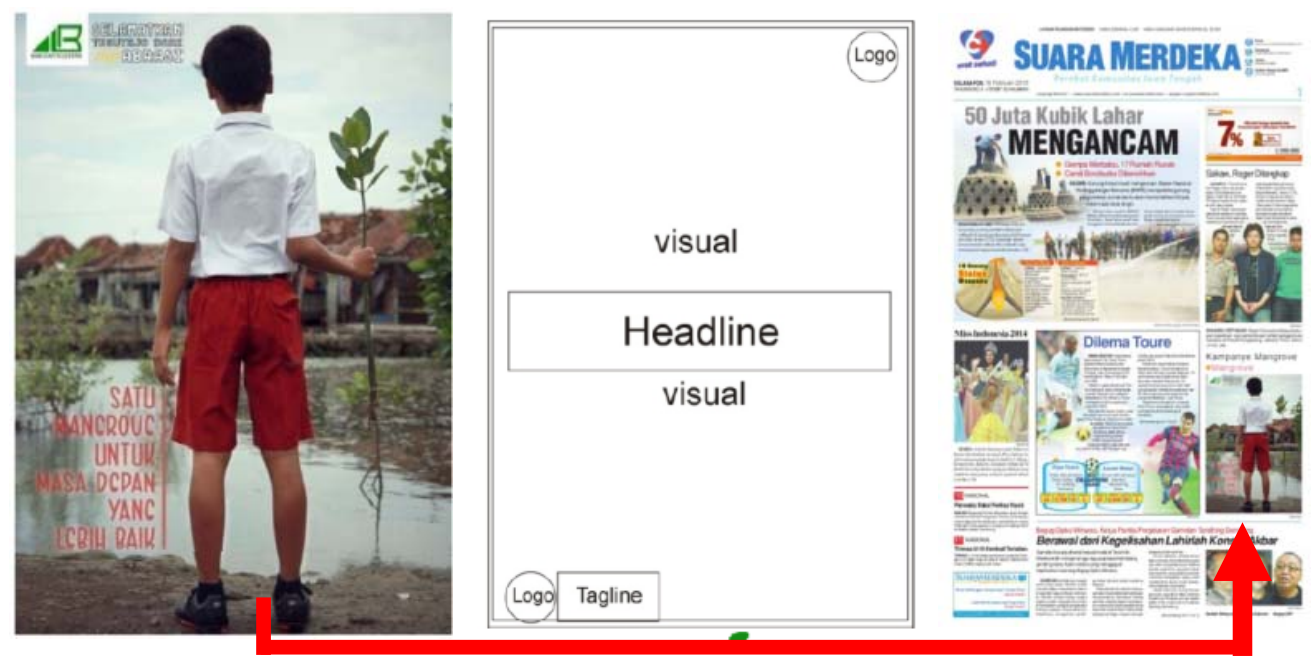

Gambar 11. Bentuk desain rancangan layout ILM dan penerapan desain pada media Koran (Reza, 2015)

\subsubsection{Iklan Layanan Masyarakat dengan media leaflet}

Selebaran atau leaflet adalah Lembaran kertas berukuran kecil mengandung pesan tercetak untuk disebarkan kepada masyarakat informasi mengenai program penanaman mangrove. Dibagikan serentak di lampu merah dan di bagikan dalam bentuk undangan kegiatan di Organisasi pencinta alam di tingkat siswa ataupun mahasiswa secara resmi.
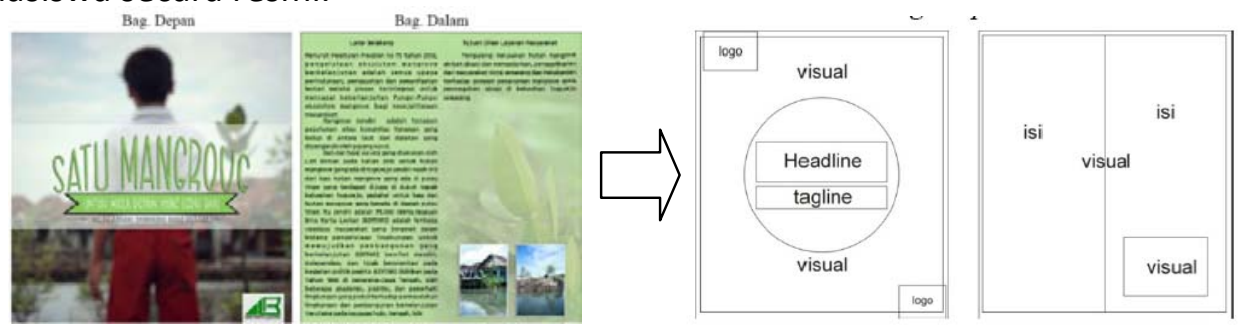

Gambar 12. Hasil desain dan konsep rancangan layout

(Reza, 2015)
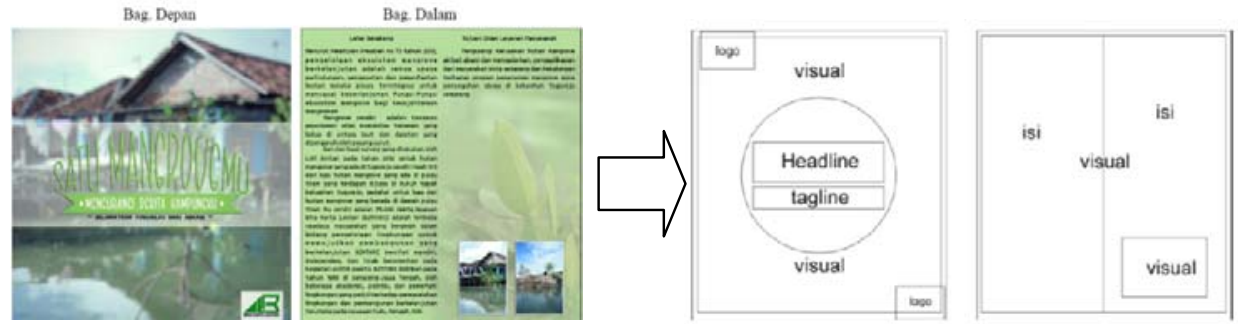

Gambar 13. Hasil desain dan konsep rancangan layout

(Reza, 2015) 
Kelebihan : Leaflet menarik untuk dilihat, Mudah untuk dimengerti, Merangsang imajinasi dalam pemahaman isi leaflet, Lebih ringkas dalam penyampaian isi informasi, Kelemahan :Leaflet hanya untuk dibagikan, tidak bisa di pajang/ ditempel.

\subsubsection{Iklan Layanan Masyarakat dengan media stiker}

Media penyampaian pesan yang aplikasinya ditempelkan mudah dilihat oleh target audiance. Stiker yang bagus hendaknya mudah diingat dari segi bentuk dan visual grafisnya. Stiker dibagikan di beserta leaflet di lampumerah serta undangan yang di bagikan kepadaOrganisasi pencinta alam di tingkat siswa ataupun mahasiswa dan di berikan kepada peserta penanaman mangrove. Keuntungan stiker adalah harga murah dan memiliki fleksibilitas dalam penerapannya.
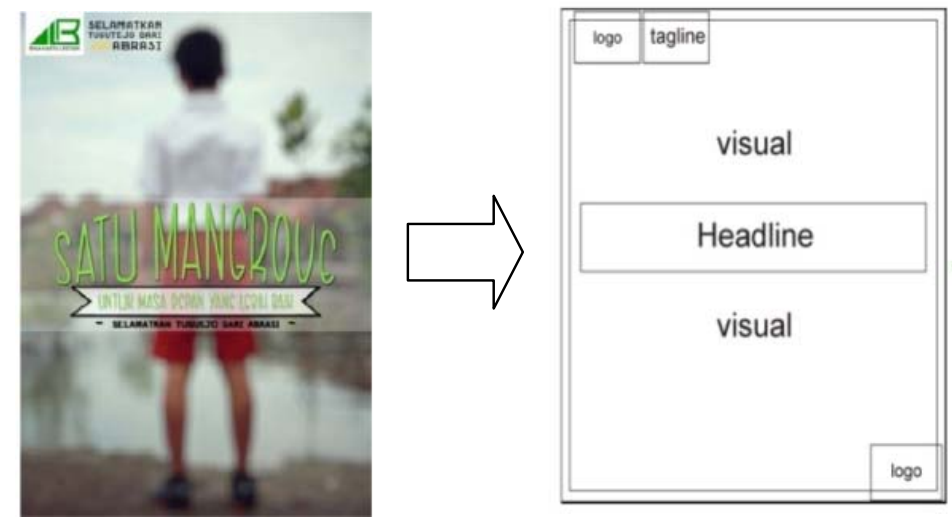

Gambar 14. Desain stker dan konsep layout desain

(Reza, 2015)

\subsubsection{Iklan Layanan Masyarakat dengan media topi}

Media ini dipilih karena merupakan media pendukung dalam sosialisasi ini.Topi merupakan media yang dapat dipakai sebagai pendukung sosialisasi dan di pakai pada saat kegiatan penanaman berlangsung sebagai identitas. Topi akan dibagikan kepada peserta penanaman mangrove. Kelebihan : Media promosi yang berjalan dan berdaya guna, sebagai identitas penanaman mangrove. Kekurangan : Tidak dipakai secara terus menerus dalam kehidupan sehari-hari.
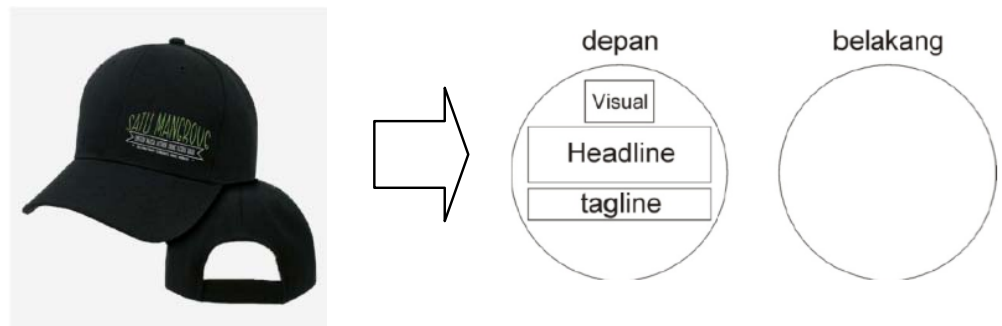

Gambar 15. Strategi kreatif melalui media topi dan konsep layout

(Reza, 2015) 


\subsubsection{Iklan Layanan Masyarakat dengan media tas}

Media ini dipilih karena merupakan media pendukung yang memiliki pengaruh yang cukup besar terhadap keberhasilan sosialisasi ini.Tas akan dibagikan kepada peserta penanaman guna menyimpan peralatan preibadi ketika berkegiatan dalam penanaman mangrove. Kelebihan : Media promosi yang berjalan dan berdaya guna, sebagai pengingat bagi pemiliknya, dan membentuk rasa bangga dan rasa memiliki bagi pemiliknya. Kekurangan : Biaya produksi mahal
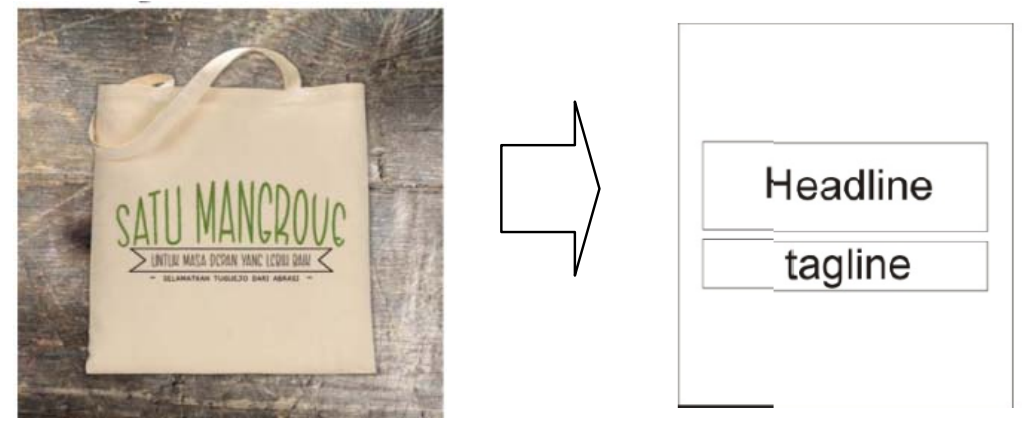

Gambar 16. Desain ILM dan konsep layout

(Reza, 2014)

\section{KESIMPULAN}

Iklan Layanan Masyarakat memiliki peran penting bagi berbagai kegiatan non-bisnis, karena dipandang dapat menggerakkan solidaritas masyarakat pada masalah-masalah social. Komunikasi visual sebagai kekuataan dalam strategi penyampai pesan iklan dipandang sebagai bahasa, maka visualisasi iklan mencakup struktur tanda yang memiliki makna. Melalui tinjauan perancangan iklan layanan masyarakat tentang BBM dan lingkungan dapat direpresentasikan sebagai strategi untuk mendekatkan ide-ide dengan masyarakat sebagai konsumen. Pemilihan iklan layanan masyarakat sebagai pijakan kreatif karena dalam perancangan melibatkan konsep-konsep dan strategi kreatif sehingga mampu mewujudkan karya yang memberl pesan kuat.

Strategi komunikasi visual yang diwujudkan guna menghasilkan karakteristik pesan yang kuat. Adapun tujuannya adalah agar pesan yang disampaikan melalui beberapa media dapat menarik beberapa khalayak. Strategi kreatif dalam rancangan ini mencakup beberapa pendekatan di antaranya: pendekatan isi pesan, what to say, dan how to say. Media ditentukan berdasarkan pertimbangan media habit, efektivitas media, dan biaya relatif (efisiensi biaya).

Media ilm sosialisasi yang digunakan adalah poster, billboard, banner, kaos, iklan surat kabar, leaflet, sticker, topi, pin, tote bag dan gantungan kunci.. Perancangan menggunakan ilustrasi dalam pengembangan desain. Teknik fotografi digunakan untuk memperkuat gambar. Daya tarik rasional pada iklan layanan masyarakat ditekankan agar dapat menggugah emosional dari audience, dengan visualisasi yang sesuai dengan permasalahan yang ada sehingga tampak persuasif dan komunikatif. 


\section{DAFTAR PUSTAKA}

Hasan Alwi. Kamus Besar Bahasa Indonesia. Jakarta : Balai Pustaka. 2001.

Jeffkins, Frank. Periklanan.Jakarta: Erlangga 1997.

Kotler, Philip. Marketing. Terj. Herujati Purwoko. Jakarta: Erlangga. 1991.

Kriyantono. Teknik Praktis Riset Komunikasi. Jakarta: Kencana Prenada Media Grup. 2008.

Lwin, May and Jim Aitchison. Clueless in Advertising Jakarta: Bhuana Ilmu Populer. 2005.

Mashur. "Perancangan Iklan Layanan Masyarakat sebagai Kampanye Penggunaan Bbm non Subsidi". Laporan Tugas Akhir. Semarang: Universitas Dian Nuswantoro. 2015.

Pujiyanto. Iklan Layanan Masyarakat. Yogyakarta: C.V. Andi Offset. (2014).

Reza Yuliyanto Tri Wibowo. "Perancangan Iklan Layanan Masyarakat Tentang Pentingnya Penanaman Mangrove di Kelurahan Tugurejo Semarang guna Pencegahan Abrasi". Laporan Tugas Akhir. Semarang: Universitas Dian Nuswantoro. 2015.

Rustan, Surianto. Layout Dasar dan Penerapannya. Jakarta: PT. Gramedia Pustaka Utama. 2009.

Sugiarto Durianto, Widjaja dan Supraktino. Invasi Pasar Dengan Iklan yang Efektif. 2003.

Tams Djayakusumah. Pengertian Periklanan. Bandung: CV Armico. 1982.

Tinarbuko, Sumbo."Memahami Tanda, Kode, dan Makna Iklan Layanan Mayarakat". Tesis. Bandung: ITB Bandung. 1998.

Yayan Suherlan. "Representasi Idiom Budaya Lokal dalam Iklan Rokok di Televisi". Jurnal Dewa Ruci. Vol. 6 no. 2 Juli 2010. Sueakarta: pascasarjana ISI Surakarta. 
Andharupa, Jurnal Desain Komunikasi Visual \& Multimedia. Vol.01 No.01 Tahun 2015 